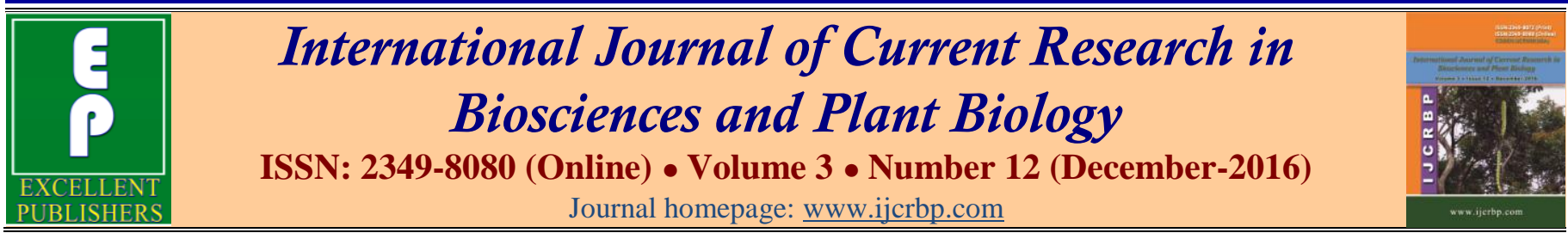

\title{
Temporal and Spatial Structure of the Reef Fish Community of the West Coast of La Paz Bay, México
}

\author{
E. Barjau-González ${ }^{*}$, J. Rodríguez-Romero ${ }^{2}$ and F. Galván-Magaña3
}

${ }^{1}$ Departamento Académico de Ciencias Marinas y Costeras, Universidad Autónoma de Baja California Sur (UABCS), Apdo. Postal 19-B, La Paz, Baja California Sur, C.P. 2308o, México

${ }^{2}$ Centro de Investigaciones Biológicas del Noroeste (CIBNOR), Apdo. Postal 128, La Paz, Baja California Sur, C.P. 23ooo, México ${ }_{3}^{3}$ Centro Interdisciplinario de Ciencias Marinas (CICIMAR-IPN), Departamento de Pesquerías y Biología Marina. Apdo. Postal 592. La Paz, Baja California Sur, México. C.P. 230oo, México

*Corresponding author.

\begin{abstract}
Ecological studies were performed to evaluate the temporal and spatial variation of reef fish communities of eight localities of the west coast of La Paz Bay, from March 2002 to April 2003. Visual census with 48 transects of $100 \times 5 \mathrm{~m}\left(500 \mathrm{~m}^{2}\right)$ were performed. Two climate seasons were detected: cold and warm. A total of 26,608 organisms from 112 species and 76 genera were observed. Relative abundance index was used to determine the most important species, which were: Abudefduf troschelii, Thalassoma lucasanum, Stegastes rectifraenum, Mulloidichthys dentatus, Chromis atrilobata, Lutjanus argentiventris, and Scarus ghobban. Diversity determined in February showed the lowest value (3.12 bits/ind.) and October showed the highest value (4.13 bits/ind.). According to the biological value index (BVI), and considering the climate seasons, species that obtained a higher score during the cold months were: Abudefduf troschelii, Mulloidichthys dentatus, Scarus ghobban, Stegastes rectifraenum, Thalassoma lucasanum, and during the warm months the same species were observed but in different order and abundance: Abudefduf troschelii, Scarus ghobban, Stegastes rectifraenum, Thalassoma lucasanum and Mulloidichthys dentatus. A higher number of species and higher abundance of fish were observed in the localities of the eastern part of the island. The principal component analysis (PCA) shows habitat characteristics and ecological features, where a strong correlation between these and rugosity was observed.
\end{abstract}

\section{Article Info}

Accepted: 16 November 2016

Available Online: 06 December 2016

\section{Keywords}

Gulf of California

La Paz Bay

Rocky reefs

Visual census

\section{Introduction}

There are different studies about the dynamic structure of fish communities of tropical and subtropical regions, including aspects such as taxonomy, community composition, habitat characterization, and reef fish species ecological role at different timescales. Some authors (Letourneur and Chabanet, 1994; Letourneur, 1996) studied the dynamic of fish communities, focusing in factors of spatial and temporal fluctuation in the reef of Union Island, in the southwest region of the Indian Ocean.

Samoilys and Gary (2000) used two different techniques of visual census (transect and mobile point counts) to estimate the abundance of coral reef fish species exploited by fisheries in two regions of the Tropical 
Pacific: The Great Barrier Reef in Australia, and Makogai reef and Duff reef in the Fiji Islands. Authors concluded that both techniques were effective, however, the mobile point counts method was more efficient.

Fariña et al. (2005) determined the reef fish community structure of Los Monjes archipelago in Venezuela, using visual census techniques such as transects $(50 \times 2 \mathrm{~m})$, recording 57 species. Diversity (H') and equity (J') were high compared to other areas both closer and far away from the study area. Later, Fariña-Pestano et al. (2009) studied the seasonal variation of the fish community structure of two reefs (rocks-stone corals and octocorals) in Bajo Las Caracas, Venezuela where 84 species were recorded in both reefs. Authors determined correlation patterns between the annual variation of fish community and seasonal physical parameters, particularly in the octocorals reef.

In recent years, studies performed in Mexico, particularly in areas near Baja California Sur, have focused on reef fish communities (e.g. diversity, abundance, richness, equity, etc.). Pérez-España et al. (1996) determined the temporal and spatial variations of the reef fish community of Espiritu Santo Island. Authors concluded that changes in the species richness were related to changes in water temperature, resulting in high species richness associated with high temperatures. A study of the fish community of Cabo Pulmo reef used visual census techniques like the stationary cylinder and literature review. In Cabo Pulmo, 236 species have been recorded; authors recorded 35 dominant species relevant because of their abundance and frequency, concluding that this reef should be considered as one of the most important localities in its region because of its fish fauna (Villarreal-Cavazos et al., 2000).

In a comparative study between the reef fish communities of Espiritu Santo Island and El Bajo Espiritu Santo seamount, authors found that temperature, depth and relative abundance of the fish fauna are associated with seasonal and temporal variations, making the island the place with most of the variation in diversity; also, there was less variation of low and high values of diversity in the seamount, considering it as a more stable ecosystem because of this attribute (Rodríguez-Romero et al., 2005). Álvarez-Filip et al. (2006) studied the temporal variation of the reef fish community structure in Cabo Pulmo, BCS. Authors found there were no statistical differences in species richness and the two climate seasons. However, they found differences in abundance among the deepest localities. In a visual census study performed on San Jose Island, 112 species were recorded. According to temperatures, two climate seasons were determined, cold and warm. Authors concluded that diversity and abundance of reef fish species in the island is associated with temperature (Barjau-González et al., 2012). The aim of the present study was to estimate spatial and temporal variations in distribution, relative abundance, diversity $\left(\mathrm{H}^{\prime}\right.$ y $\alpha$-Fisher), species richness and equity of the conspicuous reef fish community, as well as its associations with temperature, and to determine the dominant species in the community using visual census techniques.

\section{Materials and methods}

\section{Study area}

La Paz Bay is located on the southeast margin of the Baja California Peninsula; it has a semi-elliptical shape, with its major axis oriented north northwest-south southeast. It is limited by mainland towards west and south, and by the Gulf of California and Espiritu Santo and La Partida islands towards north and east (ÁlvarezArellano et al., 1997). La Paz Bay has an approximately length of $90 \mathrm{~km}$ and width of $60 \mathrm{~km}$, with an area of $4,500 \mathrm{~km}^{2}$. It has two mouths that communicate with the Gulf of California: northeast, known as Boca Grande, and east, known as Boca Chica or San Lorenzo channel. The southern limit of Boca Grande is around Los Islotes; the northwestern limit is Punta de Mechudo, where hydrodynamically there is a marked difference with the San Jose channel (Jiménez-Illescas et al., 1997) (Fig. 1).

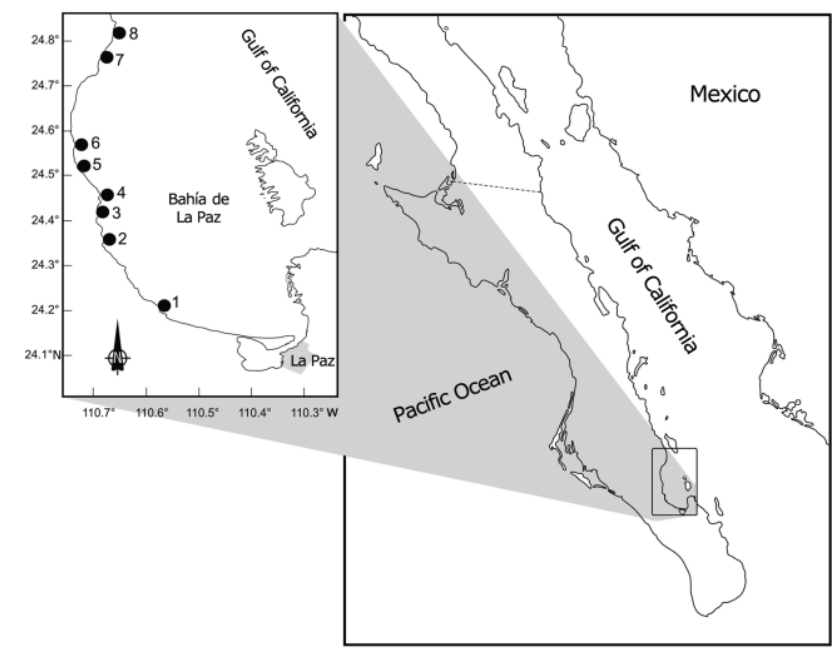

Fig. 1: Sampling localities along the coast of La Paz Bay (Bahía de La Paz): (1) Las Pacas, (2) Piedra Bola, (3) San Juan de la Costa, (4) Tarabillas, (5) El Guano, (6) El Cobre, (7) Portugués, and (8) Mechudo. 
Six bimonthly sampling trips were performed in eight localities during April, June, August, October, December of 2002 and March of 2003, to determine the fish community structure and its associations in the study area. Six visual census through freediving were performed at each sampling site, using transects of 100 $\mathrm{m}$ length and $5 \mathrm{~m}$ width (Barjau-González et al., 2012; Barjau-González et al., 2016).

Water temperature $\left( \pm 0.1^{\circ} \mathrm{C}\right)$ and dissolved oxygen $( \pm 0.1$ $\mathrm{mg} \mathrm{L}^{-1}$ ) were registered at each locality using a ISY Model 55 system, to determine the characteristics of the area. Water salinity was registered at each locality using a refractometer Atago ATC-S/Mill-E, with a scale from 0 to $100 \%$ and a minimum of $\pm 1 \%$. All data were recorded at mid water column (2.5 m deep). Type and size of substrate was determined, as well as habitat complexity, considering some components such as substrate diversity, variation in size of hollowness, percentage of life coverage (Gladfelter et al., 1980; Bell and Galzin, 1984; Roberts and Ormond, 1987; Chabanet et al., 1997; Dominici-Arosemena and Wolff, 2006) and size of rocks (Aburto-Oropeza and Balart, 2001), considering: big rocks greater than $3 \mathrm{~m}$, medium rocks from 1 to $3 \mathrm{~m}$, small rocks from $0.30 \mathrm{~cm}$ to $1 \mathrm{~m}$, and smaller rocks less than $0.30 \mathrm{~cm}$. Rugosity at each locality was determined using the profile and linear distance method (McComick,1994). Calculations were done based on proportion between chain length (10 m, caliber $3 / 16$ ") that was placed following the profile, and the linear distance of $10 \mathrm{~m}$. This proportion was used as the
Substrate Structural Complexity Index (SSCI) with values from 0 to 1 , considering a high value of rugosity when values approach zero.

Based on the information obtained by visual census, the following community attributes were determined: relative abundance, species richness (Margalef, 1995), Shannon-Wiener diversity index, Pielou's equity (Ludwig and Reynold, 1998), BVI proposed by Sanders (Sanders, 1960), relative abundance and frequency of appearance of each recorded species, which were grouped as abundant, frequent, common and rare. To establish the spatial and temporal associations of the dominant fish species with the community attributes and environmental variables, a principal component analysis (PCA) was performed. Statistical analysis was performed using Statistica v.8.0. and ecological software Primer v6.

\section{Results}

Based on the Bray-Curtis analysis, and using temperature and dominant species recorded each month, samplings performed in August, October and December were grouped as warm season, while sampling performed in March and April were grouped as cold season. Sampling from June separates from these two groups because fish species associated to cold season are present at the same time as those recorded during warm season. Therefore, based on species number and diversity, the sampling from June is considered a transition month (Fig. 2).

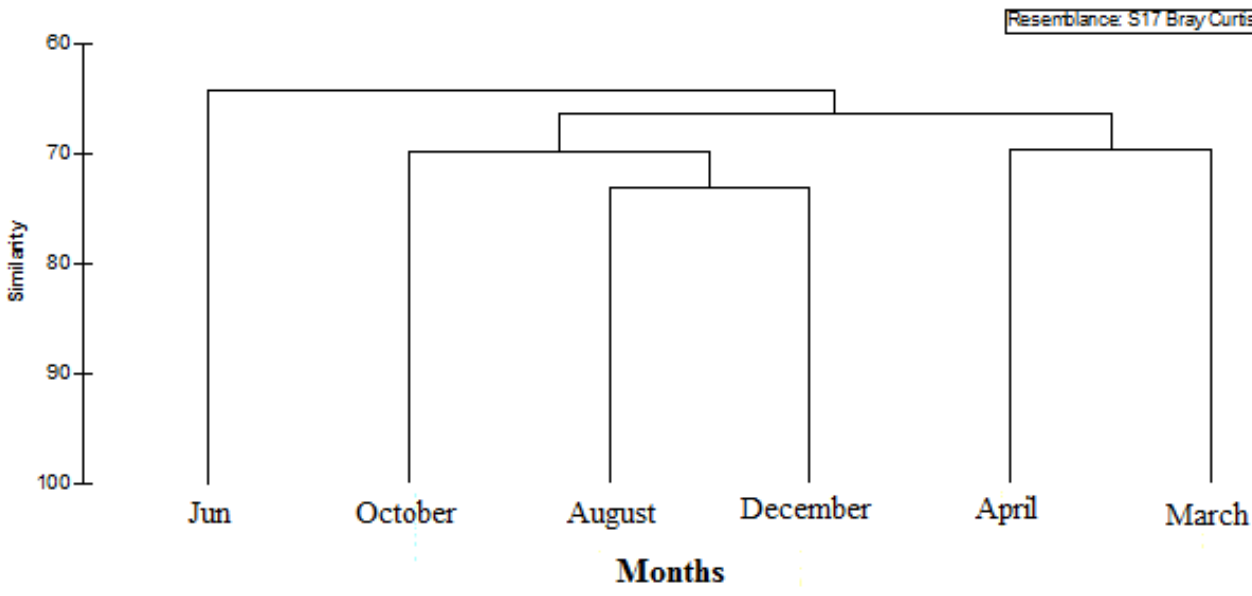

Fig. 2: Hierarchical clustering of the six samplings performed in 2002 and 2003.

Six bimonthly samplings with visual census were performed in eight localities of the west coast of $\mathrm{La} \mathrm{Paz}$ Bay. Based on average water temperature, two climate seasons were registered: cold (April, March and June) with a temperature of $22.57^{\circ} \mathrm{C}$, and warm (August, October and December) with a temperature of $27.09^{\circ} \mathrm{C}$. The highest value of salinity was recorded in august $(35.09 \%)$ and the lowest value was recorded in 
December (34.96\%). The highest value of dissolved oxygen was recorded in June $\left(7.33 \mathrm{mgl}^{-1}\right)$ and the lowest was recorded in April $\left(3.68 \mathrm{mgl}^{-1}\right)$.

Fourty eight (48) visual census were performed in eight localities from april 2002 to march 2003. A total of 24,633 organisms were recorded (density of 1.026 ind. $/ \mathrm{m}^{2}$ ); fish fauna composition on the west coast of $\mathrm{La}$ Paz Bay consisted of 92 species, from two classes, five orders, 40 families and 68 genera. Families with more recorded species were: Pomacentridae (eight species), Labridae (seven species), Haemulidae and Serranidae (six species each), Scaridae (five species), Lutjanidae and Tetraodontidae (four species each), which represents $43.48 \%$. Other families contributed with one to three species. Genera with more recorded species were: Haemulon (five species), Halichoeres and Scarus (four species each), Lutjanus and Urobatis (three species each), which represents $28.35 \%$. Other genera contributed with one or two species.

\section{Annual species richness}

Considering 92 species recorded from April 2002 to March 2003, the species richness index was 4.17. Considering this index per month, there were no significant differences $(p=0.8371)$. December registered the highest value of species richness (4.44), while October and March registered the lowest values (3.9) (Fig. 3).

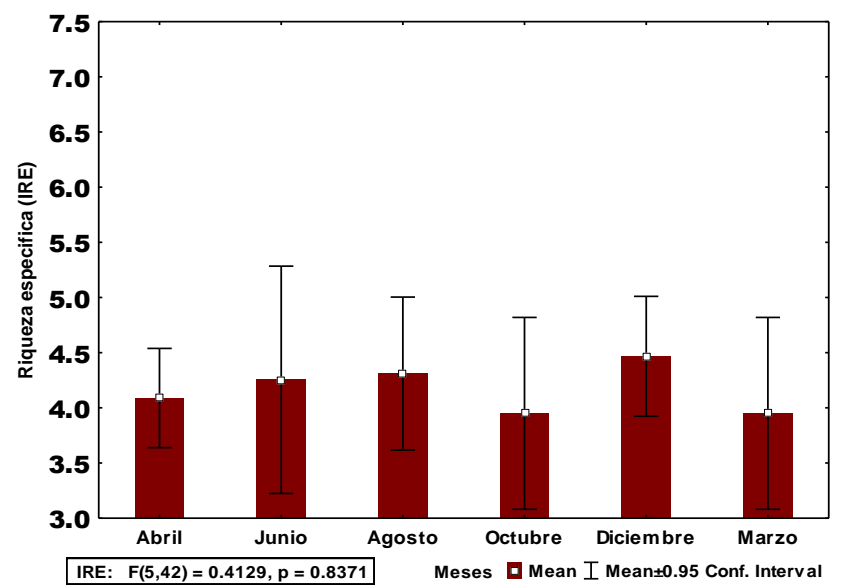

Fig. 3: Fish species richness per month.

\section{Shannon's diversity index (H')}

Shannon's diversity index did not show significant differences between months $(p=0.8567)$. December recorded the highest value (4.44bits/ind.), whereas October recorded the lowest value (3.6 bits/ind.).

\section{Fisher's alpha ( $\alpha$-Fisher)}

There were no significant differences between months $(p=0.7482)$. The average was $\mathrm{S}=8.94$, with the lowest value recorded in October $(S=7.87)$, and the highest value recorded in March $(S=10.01)$.

The variation of this index shows the highest values of diversity in two cold months, while the warmer months showed lower values, with the exception of December, that showed a higher diversity value than the one registered in April. These results show that water temperature influences fish diversity in the sampled area (Fig. 4).

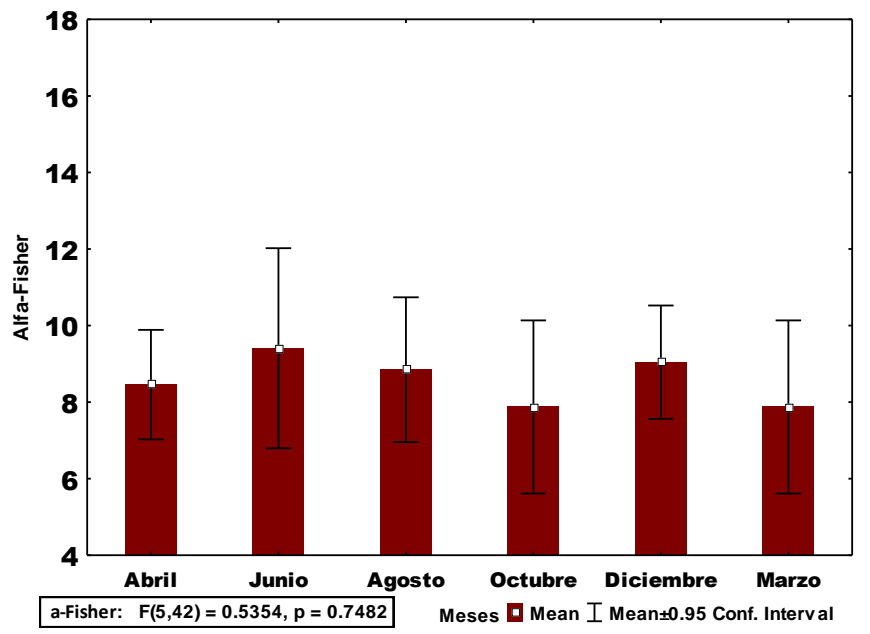

Fig. 4: Fisher's alpha per sampled month.

\section{Equity (J')}

There were no significant differences between months $(p=0.5919)$. The highest value of equity was recorded in June, and the lowest value was recorded in August, which relates to diversity ( $\left.\mathrm{H}^{\prime}\right)$.

\section{Dominance}

According to the calculated Biological Value Index (BVI), the dominant species were those that obtained 20 points onwards. During the sampled months (April 2002March 2003), 92 species were recorded in the area, with 14 species reaching the BVI values:

A. troschelii, $T$. lucasanum, $S$. rectifraenum,

H. flaviguttatum, B. polylepis, M. cephalus,

$H$. passer, $H$. sexfasciatum, $L$, argentiventris,

$M$. rosaceam, $D$. holocantus, $S$. ghobban, $P$. punctatus and $N$. denticulata. 


\section{Species classification according to their relative abundance and frequency}

According to the frequency of appearance and relative abundance of each recorded species, they were grouped into four categories:

1. Abundant species: 17 species were grouped as abundant because of their relative abundance percentage (from 1.015 to $27.40 \%$ ). The five abundant species with higher abundance and frequency were: Abudefduf troschelii, Thalassoma lucasanum, Haemulon flaviguttatum, Stegastes rectifraenum and Balistes polylepis.

2. Frequent species: 42 species were considered as frequents because of their relative abundance percentage (from 0.041 to $0.99 \%$ ). The five frequent species with higher abundance and frequency were: Prionurus punctatus, Eucinostomus currani, Mulloidichthys dentatus, Cirrhitichthys oxycephalus and Chaetodon humeralis.

3. Common species: 25 species were grouped as common because of their relative abundance percentage (from 0.008 to $0.037 \%$ ). The five common species with higher abundance and frequency were: Abudefduf concolor, Haemulon steindachneri, Kyphosus analogus, Scarus compressus and Alphestes inmaculatus.

4. Rare species: Eight species were grouped as rare because their relative abundance percentage was $0.004 \%$. The five rare species with higher abundance and frequency were: Acanthemblemaria spp., Coryphaena hipurus, Dasyatis brevis, Malacoctenus hubbsi, Muraena lentiginosa (Fig. 5).

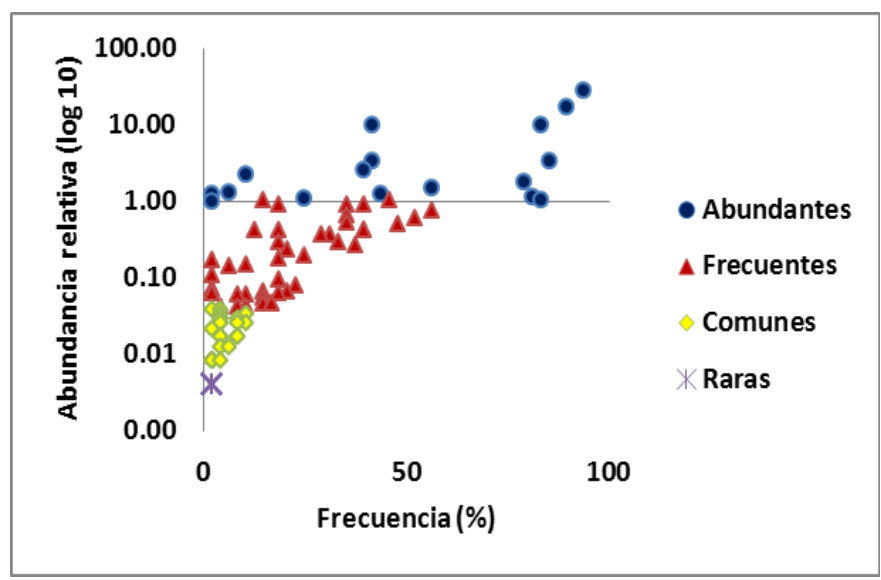

Fig. 5: Species classification according to their relative abundance and frequency.

\section{Habitat characteristics and community attributes}

The PCA showed rugosity with a higher affinity towards all community attributes, as well as substrate hardness, size of hollowness and big rocks greater than $3 \mathrm{~m}$, in three localities (Portugués, El Guano and Tarabilla). The remaining habitat characteristics showed affinity with the remaining localities (Fig. 6).

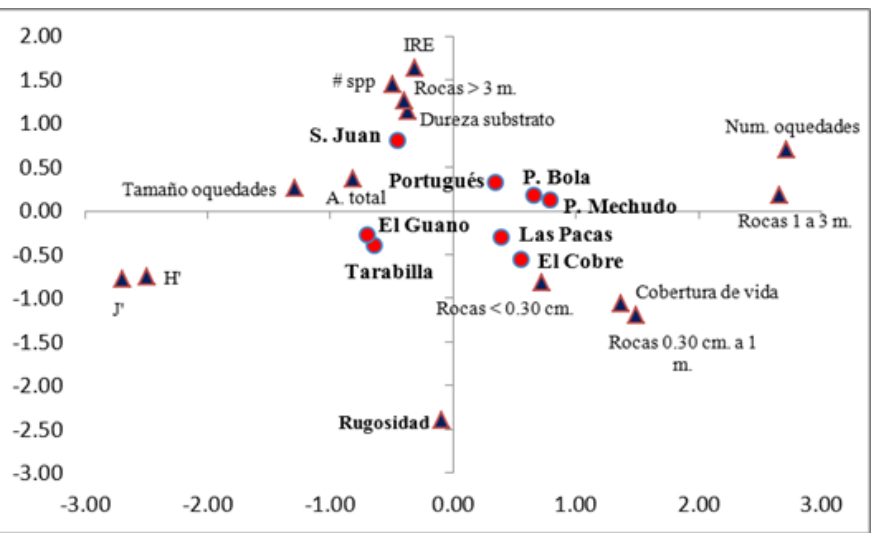

Fig. 6: Principal component analysis of habitat characteristics and fish community attributes of sampled sites of La Paz Bay.

\section{Discussion}

Annual average sea water temperature recorded was $24.8^{\circ} \mathrm{C}$. Spatially, there were no significant differences in temperature, however, there were temporal differences, which supports the presence of two climate seasons: cold and warm. In La Paz Bay, a cold season is present from March to June; however, according to the Bray-Curtis analysis (Fig. 2), June separates from the two climate seasons, making it a month of transition in the coastal zone of La Paz Bay. Also, during this month there are certain oceanographic characteristics that suggest upwelling associated to phytoplankton blooming (Fernando Aguirre Bahena, pers. comm. CICIMARIPN). These results are similar to other studies in this area (Rodríguez-Romero et al., 2005; AmadorBuenrostro et al., 2003; Galván Piña et al., 2003; MuhliaMelo et al., 2003; Aguirre-Baena, 2007), which mention that the Gulf of California has two climate seasons. According to this and the PCA results in this study, there are some fish species that have spatial and temporal affinity, and can be considered as indicators of the spatial-temporal association with temperature. One aspect of this association is higher abundance and diversity of fish species recorded in the warmer months, which suggests that temperature recorded during these months is optimal for the increase of coverage and biomass of the associated flora and fauna 
(Suárez-Castillo, 2008). Studies performed in adjacent areas that have implemented the same analysis, suggested that temperature plays an important role in the association of fish community assembly, recording a greater variation (Rodríguez-Romero, 2002; MorenoSánchez, 2009).

Regarding species composition, a greater number of fish species was recorded in this study, compared to studies performed in adjacent areas that used the same visual census technique (Aburto-Oropeza and Balart, 2001; Rodríguez-Romero, 2002; Moreno-Sánchez, 2009; Villegas-Sánchez et al., 2009), which recorded between 74 and 120 species. Environmental conditions and temporal variations have a significant impact in the number of species, and therefore, in the species richness. Thus, comparing species richness of this study with that of other fish communities of south-central Gulf of California, a latitudinal gradient was observed, where the number of species decreases from south to north (Sala et al., 2002). This is similar to a study performed in the coastal zone of the Caribbean, from Dominican Republic to Bequia (north of Granada) (Bouchon-Navarro et al., 2005), where species richness of fish communities was also influenced by a latitudinal and hydrological gradient, as well as type of habitat.

Diversity is one of the most commonly studied community attributes in Ecology. Thus, higher values of diversity are characteristic of mature and non-perturbed communities, while lower values of diversity are characteristic of constantly changing or newly established communities (Odum, 1972). Some problems may come up during Shannon's diversity index analysis because it generally lacks normality and there might be some bias due to sample size (Magurran, 1988). However, it is analysed in the present study for comparative purposes with previous studies performed in the Gulf of California. Therefore, considering temporal data from this study, a comparison was made with previous studies performed in adjacent areas (PérezEspana et al., 1996; Rodríguez-Romero et al., 2005; Álvarez-Filip et al., 2006; Aburto-Oropeza and Balart, 2001; Galván-Piña et al., 2003), which showed similar and different diversity values to those recorded in $\mathrm{La} \mathrm{Paz}$ Bay. Thus, differences in diversity can be explained as follows: 1) Although the same visual census technique and analysis was used, length of the transect was different; 2) Frequency of sampling was variable; and 3) Depth of visual census was variable, and there is greater anthropogenic pressure in the sampling sites due to their closeness to the city of La Paz.
Regarding equity, this index reflects the abundance distribution between species; with values from zero to one, with one indicating that all species are equally abundant (Magurran, 1988). The values of equity obtained in the present study are similar to diversity values recorded during all sampled season, showing spatial and temporal higher values, indicating that abundance distribution is similar between sampling sites, suggesting a low dominance and therefore stability and homogeneity in the fish community of La Paz Bay.

Regarding the ecological dominance index, in order for a species to be considered as dominant, there should be balance between species according to abundance of each sample and frequency of spatial and temporal appearance (Loya-Salinas and Escofet, 1990). Therefore, and considering only those species with BVI values above $2 \%$, the dominant species were: A. troschelii, $T$. lucasanum, $S$. rectifraenum, $H$. flaviguttatum, $B$. polylepis, $M$. cephalus, $H$. passer, $H$. sexfasciatum, $L$. argentiventris, $M$. rosacea, D. holocanthus, S. ghobban, $P$. punctatus and $N$. denticulata.

Fisher's alpha index (Fisher et al., 1943) effectively evaluates diversity according to number of organisms and number of species (Condit et al., 1996) and does not depend on sample size (Moreno, 2001; Magurran, 2004); however, it is one of the least used indexes. According to Fisher's alpha obtained in the present study, values were similar among sampled sites, and were all below 10 units. There are no previous studies were this index was evaluated.

Classification of fish species according to their relative abundance and frequency of appearance, gives an idea of their ecological role in the ecosystem. Therefore, species grouped as abundant, such as $A$. troschelii, with a relative abundance of $27.40 \%$ and frequency of appearance of $93.75 \%$, is considered a resident species because it was recorded during all sampling season. On the other hand, Scomber japonicus with a relative abundance of $1.01 \%$, and frequency of appearance of $2.08 \%$, is considered a transient species because it was recorded only one time during all sampling season. Previous studies performed in La Paz Bay have obtained similar results considering the same classification system (Aburto-Oropeza and Balart, 2001; Moreno-Sánchez, 2009; Villegas-Sánchez et al., 2009).

Distribution of reef fish is strongly associated with topographic complexity (Randall, 1993). Habitat complexity or spatial arrangement, and type of substrate 
are important factors that influence patterns of abundance of many marine species (McComick, 1994). The present study was performed in areas where rocky reefs cover between 80 and $90 \%$ of the bottom, with 10 and $20 \%$ of sand. Rugosity, substrate hardness and big rocks greater than three meters, showed a positive correlation with diversity (H'), equity (J') and total abundance. These results are similar to studies performed in other latitudes, where a positive correlation between substrate complexity and species richness and diversity was observed.

\section{Conclusion}

Water temperature showed a greater temporal variation, which is why two climate seasons were determined: cold (April, June of 2002, and March of 2003) and warm (August, October and December of 2002). June was considered as a month of transition between seasons. Considering habitat complexity and fish diversity $\left(\mathrm{H}^{\prime}\right.$ and J') of the sampled area, there is a positive correlation between them, suggesting that the more complex the habitat is, the more diversity there is.

\section{Conflict of interest statement}

Authors declare that they have no conflict of interest.

\section{Acknowledgement}

Authors acknowledge CIBNOR for providing funding under the project 'Estructura y ecología trófica de peces en el Noroeste de México'. Mario Costa from CIBNOR and Mario Silva provided underwater surveys. E.B.G. received support from Universidad Autónoma de Baja California Sur (UABCS). F.G.M. is a fellow from Instituto Politécnico Nacional (COFAA and EDI). English editing services were provided by Myrna Barjau Pérez Milicua.

\section{References}

Aburto-Oropeza, O., Balart, E., 2001. Community structure of reef fish in several habitats of a rocky reef in the Gulf of California. P.S.Z.N. Mar. Ecol-Prog. Ser. 22(4), 283-305.

Aguirre-Baena, F., 2007. Cambios temporales en los componentes y los flujos de la materia en hundimiento en cuenca Alfonso, Bahía de la Paz, durante el periodo 20022005. Tesis doctoral. CICIMAR-IPN. La Paz BCS México.

Álvarez-Arellano, A., Rojas-Soriano, H., Prieto-Mendoza, J.J., 1997. Geología de La Bahía de La Paz y Áreas Adyacentes. En: La Bahía de La Paz, Investigación y
Conservación (Eds.: Urbán-Ramírez, J., Ramírez, R. M.). UABCS-CICIMAR-SCRIPPS. pp.31-41.

Álvarez-Filip, L., Reyes-Bonilla, H., Calderón-Aguilera, E., 2006. Community structure of fishes in Cabo Pulmo Reef, Gulg of California. Mar. Ecol. 27, 253-262.

Amador-Buenrostro, A., Trasviña-Castro, A., Muhlia-Melo, A., Argote-Espinoza, M. L., 2003. Influence of EBES seamount and Farallon basin on coastal circulation in the Gulf of California, Mexico. Geofis Int. 42, 407-408.

Barjau-González, E., Rodríguez-Romero, J., Galván-Magaña, F., Maldonado-García, M., 2016. Seasonal shift in the taxonomic diversity of rocky reef fishes in the southwestern Gulf of California. Rev. Biol. Mar. Oceanogr. 51(1), 11-19.

Barjau-González, E., Rodriguez-Romero, J., Galván-Magaña, F., Gutiérrez-Sánchez, F., Lopez, J., 2012. Estructura temporal y espacial de la comunidad de peces arrecifales de la Isla San José, Golfo de California, México. Rev. Biol. Trop. (Int. J. Trop. Biol. ISSN-0034-7744). 60(2), 649-667.

Bell, J. D., Galzin, R., 1984. Influence of live coral cover on coral-reef fish communities. Mar. Ecol. Prog-Ser. 15, 265274.

Bouchon-Navarro, Y., Bouchon, C., Louis, M., Legendre, O., 2005. Biogeographic patterns of coastal fish assemblages in the West Indies. J. Exp. Mar. Biol. Ecol. 315, 31-47.

Chabanet, P., Ralambondrainy, H., Amanieu, M., Faure, G., Galzin, R., 1997. Relationships between coral reef substrata and fish. Coral Reefs. 16, 93-102.

Condit, R., Hubbell, S. P., Foster, R. B., 1996. Changes in tree species abundance in a Neotropical forest: Impact of climate change. J. Trop. Ecol. 12, 231-256.

Dominici-Arosemena, A., Wolff, M., 2006. Reef fish community structure in the Tropical Pacific (Panamá): Living on a relatively stable rocky reef environment. Helgoland Mar. Res. 60, 287-305.

Fariña, A., Bellorín, A., Sant, S., Méndez, E., 2005. Estructura de la comunidad de peces en un arrecife del Archipiélago Los Monjes, Venezuela. Cienc. Mar. 31(3), 585-591.

Fariña-Pestano, A. R., Méndez De Elgueazabal, E., 2009. Variación estacional de la estructura comunitaria de peces en dos arrecifes: rocoso-coralino y de octocorales, en el Bajo Las Caracas, Venezuela. Rev. Biol. Mar. Oceanogr. 44(1), 153-162.

Fisher, R., Corbet, S., Williams, C., 1943. The relation between the number of species and the number of individual in a random sample of an animal population. $\mathbf{J}$. Anim. Ecol. 12, 42-58.

Galván-Piña, V. H., Galván-Magaña, F., Abitia-Cárdenas, L., Gutiérrez-Sánchez, F. J., Rodríguez-Romero, J., 2003. Seasonal structure of fish assemblages in rocky and sandy habitats in Bahia de La Paz, Mexico. Bull. Mar. Sci. 72(1), 19-35.

Gladfelter, W. B., Ogden, J. C., Gladfelter, E. H., 1980. Similarity and diversity among coral reef fish communities: A comparison between tropical western Atlantic (Virgin Islands) and tropical central Pacific 
(Marshal Islands) patch reefs. Ecology. 61, 1156-1168.

Jiménez-Illescas, A., Obeso, N.M., Salas de León, D., 1997. Oceanografía Física de la Bahía de La Paz, B.C.S. En: La Bahía de La Paz, Investigación y Conservación (Eds.: Urbán, R.J., Ramírez, R.M.). UABCS-CICIMARSCRIPPS. pp.31-41.

Letourneur, Y., 1996. Dynamic of fish communities on Reunion fringing reef, Indian Ocean. I Patterns of spatial fluctuation. J. Exp. Mar. Biol. Ecol. 195, 1-30.

Letourneur, Y., Chabanet, P., 1994. Spatio-temporal fluctuations on the ichthyofauna of coral reef flats of Reunion island (S.W. Indian Ocean). Cybium. 18(1), 2538.

Loya-Salinas, D. H., Escofet, A., 1990. Aportación al cálculo del índice de valor biológico, (Sanders, 1960). Cienc. Mar. 16 (2), 97-115.

Ludwig, J., Reynold, J., 1998. Statistical Ecology. John Wiley \& Sons Inc., New York. 351p.

Magurran, A., 1988. Ecological Diversity and its Measurement. Princeton, NJ. Princeton, University Press.

Magurran, A., 2004. Measuring Biological Diversity. Blackwell Publishing, London.

Margalef, R., 1995. Ecología. Barcelona, España. Omega. 951p.

McComick, M. I., 1994. Comparison of field methods for measuring surface topography and their associations with tropical reef fish assemblage. Mar. Ecol. Prog-Ser. 112, 87-96.

Moreno, C. E., 2001. Métodos para medir la biodiversidad. M\&T- Manuales y tesis SEA, Vol. I. Zaragoza, España.

Moreno-Sánchez, X. G., 2009. Estructura y organización trófica de la ictiofauna del arrecife de los Frailes BCS México. Tesis Doctoral. CICIMAR-IPN. La Paz, BCS Mexico.

Muhlia-Melo, A., Klimley, P., González-Armas, R., Jorgensen, S., Trasviña-Castro, A., Rodríguez-Romero, J., AmadorBuenrostro, A., 2003. Pelagic fish assemblages at the Espíritu Santo seamount in the Gulf of California during El Niño 1997-1998 and non-El Niño conditions. Geofis Int. 42(3), 1-9.

Odum, E. P., 1972. Ecología. 3rd Edn. Ed Interamericana. México.

Pérez-España, E. H., Galván-Magaña, F., Abitia-Cárdenas,
L.A., 1996. Variaciones temporales y espaciales en la estructura de la comunidad de peces de arrecifes rocosos del suroeste del Golfo de California, México. Cienc. Mar. 22(3), 273-294.

Randall, J. E., 1993. An Analysis of fish populations of artificial and natural reefs in the Virgin Island. Carib. J. Sci. 3, 31-48.

Roberts, C. M., Ormond, F. G., 1987. Habitat complexity and coral reef fish diversity and abundance on Red Sea fringing reefs. Mar. Ecol-Prog. Ser. 41, 1-8.

Rodríguez-Romero, J., 2002. Análisis ecológico de la comunidad de peces de la Isla Espíritu Santo y la montaña submarina el Bajo Espíritu Santo en el sur del Golfo de California, México. Tesis Doctoral, CIBNOR. La Paz BCS México.

Rodríguez-Romero, J., Muhlia-Melo, A. F., Galván-Magaña, F., Gutiérrez-Sánchez, F., Gracia-López, V., 2005. Fish assemblages around Espiritu Santo Island and Espiritu Santo Seamount in the lower Gulf of California, Mexico. Bull. Mar. Sci. 77(1), 33-50.

Sala, E., Aburto-Oropeza, O., Paredes, G., Parra, I., Barrera, J.C., Dayton, P.K., 2002. A general model for designing networks of marine reserves. Science. 298, 1991-1993.

Samoilys, M.A., Gary, C., 2000. Determining methods of underwater visual census for estimating the abundance of coral reef fishes. Env. Biol. Fish. 57, 289-304.

Sanders, H.L., 1960. Benthic studies in Buzzards Bay. III. The structure of the soft-bottom community. Limnol. Oceanogr. 5, 138-153.

Suárez-Castillo, A.N., 2008. Fauna asociada a mantos de Sargassum (Ochrophyta: Fucales) en el Sauzoso, Baja California Sur, México. Tesis de maestría. CICIMARIPN. La Paz BCS Mexico.

Villarreal-Cavazos, A., Reyes-Bonilla, H., Bermúdez-Almada, B., Arizpe-Covarrubias, O., 2000. Los peces del arrecife de Cabo Pulmo, Golfo de California, México: Lista sistemática y aspectos de abundancia y biogeografía. Rev. Biól. Trop. 48, 2-3.

Villegas-Sánchez, C.A., Abitia-Cárdenas, L.A., GutiérrezSánchez, F. J., Galván-Magaña, F., 2009. Rocky-reef fish assemblages at San José Island, Mexico. Rev. Mex. Biodiver. 80, 169-179.

\section{How to cite this article:}

Barjau-González, E., Rodríguez-Romero, J., Galván-Magaña, F., 2016. Temporal and spatial structure of the reef fish community of the west coast of La Paz Bay, México. Int. J. Curr. Res. Biosci. Plant Biol. 3(12), 28-35. doi: http://dx.doi.org/10.20546/ijcrbp.2016.312.004 